\title{
ANALISIS DESTINASI PARIWISATA PULAU UNTUNG JAWA DI KEPULAUAN SERIBU JAKARTA
}

\author{
Uuh Sukaesih", Farida $^{2}$, Miswan ${ }^{3}$ \\ Fakultas Ekonomi dan Bisnis, Universitas Sahid Jakarta \\ Jl. Soepomo No 84, Jakarta Selatan \\ Email Korespondensi: sukaesihuuh@yahoo.co.id
}

\begin{abstract}
ABSTRAK
Tujuan dari penelitian ini adalah adalah : 1) Untuk mengetahui karakteristik wisatawan Pulau Untung Jawa, 2) Untuk mengkaji destinasi pariwisata Pulau Untung Jawa di Kepulauan Seribu Jakarta. Penelitian dilakukan dengan menyebarkan kuesioner kepada100 wisatawan yaitu orang yang sudah mengunjungi Pulau Untung Jawa di Kepulauan Seribu Jakarta. Metode analisis dilakukan dengan analisis deskriptif, yaitu dengan mendeskriptifkan atau menggambarkan tentang hasil dari penelitian mengenai destinasi pariwisata yang diukur dengan menggunakan skala interval dari 1 sampai 4, yang selanjutnya dihitung rata-ratanya dan disajikan dalam tabel. Hasil penelitian yaitu : 1) Karakteristik wisatawan yang datang ke Pulau Untung Jawa Kepulauan Seribu Jakarta yaitu : Laki-laki 53 persen, 76 persen berusia 17 tahun sampai 30 tahun, 62 persen berpendidikan SLTA, 38 persen berasal dari wilayah Tangerang, 64 persen pelajar/mahasiswa dan pegawai swasta, 60 persen berpendapatan kurang atau sama dengan Rp 3.000 .000 per bulan. 2) Penilaian wisatawan mengenai destinasi pariwisata Pulau Untung Jawa di Kepulauan Seribu Jakarta dengan skala 1 sampai 4, diperoleh rata-rata $=3.00$ (kategori baik).
\end{abstract}

Kata Kunci : Destinasi Pariwisata, Pulau Untung Jawa, Kepulauan Seribu

\begin{abstract}
The objectives of this study are: 1) To find out the characteristics of the tourists of Untung Jawa Island, 2) To study the tourism destinations of Untung Jawa Island in the Thousand Islands Jakarta. The research was conducted by distributing questionnaires to 100 tourists, namely people who had visited Untung Jawa Island in the Thousand Islands Jakarta. The method of analysis is carried out by descriptive analysis, namely by describing or describing the results of research on tourism destinations that are measured using an interval scale from 1 to 4 , which is then averaged and presented in the table. The results of the study were: 1) Characteristics of tourists who came to the Thousand Islands Jakarta Untung Jawa Island namely: Men 53 percent, 76 percent aged 17 years to 30 years, 62 percent had high school education, 38 percent came from the Tangerang area, 64 percent students / private students and employees, 60 percent earn less than or equal to Rp 3,000,000 per month. 2) Rating of tourists regarding Untung Jawa Island tourism destinations in the Thousand Islands Jakarta on a scale of 1 to 4, obtained an average = 3.00 (good category).
\end{abstract}

Keywords: Tourism Destinations, Untung Jawa Island, Thousand Islands 


\section{PENDAHULUAN}

Industri pariwisata menjadi sektor terpenting dalam suatu negara termasuk untuk Negara Indonesia karena industri pariwisata menjadi salah satu sumber penghasil devisa, dapat meningkatkan pertumbuhan ekonomi, dapat meningkatkan kesejahteraan rakyat, membuka lapangan kerja, dan mengatasi pengangguran.

Kepulauan Seribu merupakan wilayah Administratif DKI Jakarta yang terdiri dari pulau-pulau sekitar 110 pulau,terbagidalampulau yang berpenduduk ( PulauPramuka, PulauTidung, PulauUntungJawa, PulauHarapan, PulauKelapa, PulauPari/Lancang), pulau yang dimanfaatkanuntuk resort (Pulau Ayer, PulauBidadari, PulauKotok Tengah, PulauSepa, PulauPutri, PulauMacan, PulauPantara), danPulaucagaralam yang dimanfaatkanuntukkonservasi (PulauOnrust, PulauRambut, PulauKelor). Jumlah wisatawan ke Kepulauan Seribu Jakartatahun 2015 dan tahun 2016 disajikan pada Tabel 1 .

Tabel 1. Jumlah Wisatawan ke Kepulauan Seribu Jakarta Tahun 2015 dan 2016

\begin{tabular}{|l|l|c|c|}
\hline No & Nama Pulau & $\begin{array}{l}2015 \\
\text { (Orang) }\end{array}$ & $\begin{array}{l}2016 \\
\text { (Orang) }\end{array}$ \\
\hline \multicolumn{2}{|l|}{ Pulau Berpenduduk } & 125568 & 88527 \\
\hline 1. & Pulau Pramuka & 289975 & 146351 \\
\hline 2. & Pulau Tidung & 430899 & 252669 \\
\hline 3. & Pulau UntungJawa & 122114 & 86106 \\
\hline 4. & Pulau Harapan & 27000 & 35364 \\
\hline 5. & Pulau Kelapa & 207103 & 116107 \\
\hline 6. & Pulau Pari/Lancang & 1202661 & 17392 \\
\hline 7 & PulauLainnya & $(96,06 \%)$ & $(84,8 \%)$ \\
\hline PulauBerpendududk & 49225 & 126812 \\
& $(3,94 \%)$ & $(15,2 \%)$ \\
\hline $\begin{array}{l}\text { Pulau Resort, Konservasi, } \\
\text { danlainnya (Pulau Tidak } \\
\text { berpenduduk) }\end{array}$ & 1251886 & 834544 \\
\hline \multicolumn{2}{|l|}{ Jumlah } & & \\
\hline
\end{tabular}

Sumber : Dinas Pariwisata dan Kebudayaan Kepulauan Seribu 2015, 2016

Berdasarkan Tabel 1 dapat dilihat bahwa jumlah wisatawan kepulau berpenduduk lebih banyak ( tahun 2015 sebanyak 96,06 \% dan tahun 2016 sebanyak 84,8 \%) dibanding ke pulauyang tidak berpenduduk, hal inidikarenakanpulau yang berpenduduk sudah lebih baik dari segi fasilitas, sarana dan prasarana, serta mudahnya transportasi menuju pulau tersebut. Selain itu harga penginapan di pulau yang berpenduduk lebih murah dibandingkan dengan pulau yang tidak berpenduduk.

Usaha pengembangan destinasi pariwisata perlu dilakukan dan ditingkatkan agar destinasipariwisata dapat berkembang dan memiliki daya tarik tersendiri dibandingkan dengan destinasipariwisata lainnya. Meskipun suatu destinasipariwisata telah memiliki potensi wisata yang baik, tetapi jika tidak didukung dengan pembangunan dan pemeliharaan sarana dan prasarana yang baik, maka destinasipariwisata tersebut tidak akan berkembang dengan baik. 
Pengelola destinasipariwisata selain harus mengembangkan potensi yang ada, juga harus memberikan pelayanan yang baik kepada wisatawan agar wisatawan merasa nyaman dan puas ketika berkunjung ke objek wisata dan akhirnya akan tertarik untuk berkunjung kembali.

Tujuan dari penelitian ini yaitu :1) Untuk mengetahuikarakteristik wisatawan Pulau Untung Jawa di Kepulauan Seribu Jakarta, 2) Untuk mengetahuidestinasi pariwisata(data tarik wisata, fasilitas,dan aksesibilitas )Pulau Untung Jawadi Kepulauan Seribu Jakarta.

\section{Pengertian Pariwisata}

Istilah pariwisata (tourism) baru muncul di masyarakat kira-kira pada abad ke- 18, khususnya setelah revolusi industri di Inggris. Istilah pariwisata berasal dari dilaksanakannya kegiatan wisata (tour). Dalam Undang-Undang RI nomor 10 tahun 2009 tentang Kepariwisataan menjelaskan bahwa, Pariwisata adalah berbagai macam kegiatan wisata dan didukung berbagai fasilitas serta layanan yang disediakan oleh masyarakat, pengusaha, dan pemerintah. Sedangkan wisata merupakan kegiatan perjalanan yang dilakukan oleh seseorang atau sekelompok orang dengan mengunjungi tempat tertentu untuk tujuan rekreasi, pengembangan pribadi, atau mempelajari keunikan daya tarik wisata yang dikunjungi, dalam jangka waktu sementara.

Menurut Mayers (2009), pariwisata adalah aktivitas perjalanan yang dilakukan sementara waktu dari tempat tinggal semula ke daerah tujuan dengan alasan bukan untuk menetap atau mencari nafkah melainkan hanya untuk memenuhi rasa ingin tahu, menghabiskan waktu senggang atau berlibur. Sejalan dengan definisi tersebut, Richardson dan Fluker (2009), mendefinisikan pariwisata sebagai kegiatan atau orangorang yang melakukan perjalanan dan tinggal di luar lingkungan mereka selama tidak lebih dari satu tahun berturut-turut untuk bersantai, bisnis, dan tujuan lainnya.

\section{Pengertian Destinasi Pariwisata}

Dalam Undang-undang Nomor 10 tahun 2009 tentang Kepariwisataan disebutkan : Daerah tujuan pariwisata yang selanjutnya disebut Destinasi Pariwisata adalah kawasan geografis yang berada dalam satu atau lebih wilayah administratif yang di dalamnya terdapat daya tarik wisata, fasilitas umum, fasilitas pariwisata, aksesibilitas, serta masyarakat yang saling terkait dan melengkapi terwujudnya kepariwisataan.

Menurut Sunaryo (2013 : 159) kerangka pengembangan Destinasi Pariwisata paling tidak harus mencakup komponen-komponen utama sebagai berikut:

a Objek dan Daya Tarik (Atractions) yang mencakup: daya tarik yang bisa berbasis utama pada kekayaan alam, budaya, maupun buatan/artificial, seperti event atau yang sering disebut sebagai minat khusus (special interent).

b. Aksesibilitas (Accessibility), yang mencakup dukungan sistem transportasi yang meliputi: rute atau jalur transportasi, fasilitas terminal, bandara, pelabuhan dan moda transportasi yang lain.

c. Amenitas (Amenities), yang mencakup fasilitas penunjang dan pendukung wisata yang meliputi: akomodasi, rumah makan (food and baverage), retail, toko cinderamata, fasilitas penukaran uang, biro perjalanan, pusat informasi wisata, dan fasilitas kenyamanan lainnya.

d. Fasilitas pendukung (Ancillary Services) yaitu ketersediaan fasilitas pendukung yang digunakan oleh wisatawan, seperti bank, telekomunikasi, pos, rumah sakit, dan sebagainya. 
e. Kelembagaan (Institutions) yaitu terkait dengan keberadaan dan peran masing- masing unsur dalam mendukung terlaksananya kegiatan pariwisata termasuk masyarakat setempat sebagai tuan rumah (host).

Keberhasilan suatu destinasi pariwisata dalam menarik kunjungan wisatawan tentunya tidak lepas dari kecermatan pengelola dalam memahami karakter dan ekspektasi pasar yang selanjutnya dijadikan acuan dalam pengembangan produk dan layanan serta fasilitas pendukung wisata yang terkait di dalamnya.

\section{METODE PENELITIAN}

\section{Jenis Data dan Sumber Data}

Jenis data dan sumber data yang utama dalam penelitian ini yaitudata primeryang diperoleh secara langsung dengan menggunakan kuisioner yang diisi oleh wisatawan mengenai karakteristik wisatawan, dan pendapat atau penilaian wisatawan mengenai destinasi pariwisata di Pulau Untung JawaKepulauan Seribu Jakarta.

\section{Populasi dan Sampel}

Padapenelitian ini yangmenjadipopulasiadalahwisatawan kePulau Untung JawaKepulauan Seribu Jakarta yang menurut data dari Dinas Pariwisata dan Kebudayaan Kepulauan Seribu pada tahun 2016 berjumlah 252669 orang. Mengingat data tahun 2017 belum tersedia, maka polulasi dalam penelitian ini menggunakan data tahun 2016 yaitusebanyak 252669 orang.

Karena keterbatasan tenaga, biaya, dan waktu yang tersedia, maka penelitian dilakukan terhadap sampel dengan penetuan ukuran atau jumlah sampel dengan rumus Slovin yaitu :

$$
\mathrm{n}=\begin{array}{cc|}
\mathrm{N} & 252669 \\
\hline \mathrm{N}\left(\mathrm{N}(\mathrm{e})^{2}\right. & =99,96 \\
\hline
\end{array}
$$

dengan demikian jumlah sampel dalam penelitian ini sebanyak 100 orang.

Untuk menentukan sampel terpilih digunakan teknik purposive sampling yaitu memilih orang yang dianggap mewakili yaitu orang yang telah mengunjungi Pulau Untung Jawa di Kepulauan Seribu Jakarta.

\section{Operasional Variabel}

Dalam melakukan penelitian operasional variabel dijadikan panduan dalam melakukan tahap penelitian untuk mempermudah dalam pembuatan kuesioner. Operasionalisasi variabel dalam penelitian ini disajikan pada Tabel 2 . 
Tabel 2. Operasionalisasi Variabel Penelitian

\begin{tabular}{|c|c|c|c|}
\hline Variabel & Konsep Variabel & Dimensi & Indikator \\
\hline \multirow[t]{3}{*}{$\begin{array}{l}\text { DestinasiPar } \\
\text { iwisata }\end{array}$} & \multirow[t]{3}{*}{$\begin{array}{l}\text { Daerah tujuan wisata } \\
\text { yaitu kawasan geografis } \\
\text { yang berada dalam satu } \\
\text { atau lebih wilayah } \\
\text { administrative }\end{array}$} & a. Daya Tarik Wisata & $\begin{array}{ll}\text { 1. } & \text { Keindahan pantai } \\
\text { 2. } & \text { Keindahan terumbu } \\
\text { karang/wisata bawah air } \\
\text { 3. } & \text { Kebersihan pantai }\end{array}$ \\
\hline & & b. Fasilitas & $\begin{array}{l}\text { 1. Ketersediaan penginapan } \\
\text { 2. Keterjangkauan harga } \\
\text { penginapan } \\
\text { 3. Ketersediaan penjual makanan } \\
\text { dan minuman } \\
\text { 4. Keterjangkauan harga } \\
\text { makanan dan minuman } \\
\text { 5. Ketersediaan fasilitas } \\
\text { permainan air } \\
\text { 6. Keterjangkauan harga fasilitas } \\
\text { permainan air } \\
\text { 7. Ketersediaan air bersih }\end{array}$ \\
\hline & & $\begin{array}{l}\text { Aksesibilitas dan } \\
\text { Transportasi }\end{array}$ & $\begin{array}{ll}\text { 1. } & \text { Kemudahan transportasi } \\
\text { 2. } & \text { Kenyamanantrasportasi } \\
\text { 3. } & \text { Keamanantrasportasi } \\
\text { 4. } & \text { Keterjangkauan biaya } \\
& \text { transportasi }\end{array}$ \\
\hline
\end{tabular}

\section{Uji Validitas dan Reliabilitas}

Uji validitas digunakan untuk mengetahui apakah alat ukur dalam hal ini kuisioner yang telah dibuat dapat digunakan untuk mengukur apa yang akan diukur atau diteliti secara tepat. Untuk menguji validitas kuisioner digunakan koefisien koreasi (r). Hasil pengolahan data mengenai nilai koefisien korelasi dan nilai signifikansi untuk kuesioner kualitas destinasi pariwisata Pulau Untung Jawa disajikan pada Tabel 4.

Tabel 3. Nilai Koefisien Korelasi (r) dan Nilai Signifikansi Kuesioner Destinasi Pariwisata Pulau Untung Jawa

\begin{tabular}{|l|l|l|l|}
\hline Dimensi & Indikator & Nilai r & Nilai Signifikansi \\
\hline \multirow{5}{*}{ Daya Tarik Wisata } & 1. Keindahan pantai & 0,631 & 0,000 \\
\cline { 2 - 4 } & 2. Keindahan terumbu karang/wisata bawah air & 0,738 & 0,000 \\
\cline { 2 - 4 } & 3. Kebersihan pantai & 0,618 & 0,000 \\
\hline Fasilitas & 1. Ketersediaan Penginapan & 0,839 & 0,000 \\
\cline { 2 - 4 } & 2. Keterjangkauan Harga Penginapan & 0,410 & 0,000 \\
\cline { 2 - 4 } & 3. Ketersediaan Penjual Makanan dan Minuman & 0,622 & 0,000 \\
\cline { 2 - 4 } & $\begin{array}{l}\text { 4. Keterjangkauan Harga Makanan dan } \\
\text { Minuman }\end{array}$ & 0,675 & 0,000 \\
\cline { 2 - 4 } & 5. Ketersediaan Fasilitas Permainan Air & 0,848 & 0,000 \\
\cline { 2 - 4 } & 6. Keterjangkauan Harga Fasilitas Permaian air & 0,716 & 0,000 \\
\cline { 2 - 4 } & 7. Ketersediaan Air Bersih & 0,782 & 0,000 \\
\hline Aksesibilitas & 1. Kemudahan Transportasi & 0,296 & 0,022 \\
\cline { 2 - 4 } & 2. Kenyamanan Transportasi & 0,795 & 0,000 \\
\cline { 2 - 4 } & 3. Keamanan Transportasi & 0,758 & 0,000 \\
\cline { 2 - 4 } & 4. Keterjangkauan Biaya Transportasi & 0,642 & 0,000 \\
\hline
\end{tabular}

Sumber : Data Primer diolah, 2018 
Dari Tabel 3 dapat dilihat bahwa nilai signifikansi untuk koefisien korelasi (r) untuk semua indikator yang ada dalam kuesioner lebih kecil dari 0,05 (5 persen), hal tersebut menunjukan bahwa kuisioner yang telah dibuat dapat digunakan untuk mengukur apa yang akan diukur atau diteliti secara tepat. Uji reliabilitas digunakan untuk mengukur kemantapan atau keandalan suatu instrument atau alat ukur yang digunakan. Suatu alat ukur dikatakan memiliki reliabilitas yang tinggi atau dapat dipercaya jika alat ukur tersebut jika alat ukur memberikan hasil pengukuran yang tidak berubah-ubah dan akan memberikan hasil yang sama meskipun digunakan berkali-kali oleh peneliti yang sama maupun oleh peneliti yang berbeda. Pada penelitian ini akan digunakan koefisien Croncbach Alphadalam melihat hasil uji reliabilitas. Suatu instrument dapat dikatakan andal(reliable) jika memiliki koefisien keandalan (reliabilitas) sebesar 0,6 atau lebih dengan kriteria tinggi atau sangat tinggi. Hasil pengolahan data mengenai nilai Croncbach Alpha untuk kuesioner kualitas destinasi pariwisata Pulau Untung Jawa disajikan pada Tabel 4.

Tabel 4. Nilai Koefisien Croncbach Alpha Destinasi Pariwisata Pulau Untung Jawa

\begin{tabular}{|l|l|l|}
\hline Destinasi Pariwisata & Nilai Koefisien Croncbach Alpha & Kriteria \\
\hline 1.Daya Tarik Wisata & 0,840 & Sangat Tinggi \\
\hline 2. Fasilitas & 0,734 & Tinggi \\
\hline 3. Aksesibilitas & 0,741 & Tinggi \\
\hline
\end{tabular}

Sumber : Data Primer diolah,2018

Dari Tabel 4 dapat dilihat bahwa nilai Nilai Koefisien Croncbach Alphayang menunjukkan nilai reliabilitas lebih besar dari 6 dengan kriteria tinggi dan sangat tinggi. Dengan demikian kuesioner yang digunakan dapat diandalkan.

\section{Metode Analisis}

Metode analisis pada penelitian ini yaitu sebagai berikut:

1. Untuk mengetahui karakteristik wisatawan ke Pulau Untung Jawa dilakukan dengan analisis deskriptif yaitu dengan mendeskripsikanatau menggambarkan tentang karakteristik wisatawan ke Pulau Untung Jawadengan menghitung jumlah, dan persentase yang selanjutnya disajikan dalam Tabel.

2. Untuk mengetahui pendapat wisatawan mengenai kualitas destinasi pariwisata Pulau Untung Jawa dilakukan dengan analisis deskriptif yaitu dengan mendeskripsikan atau menggambarkan tentang penilaian wisatawan mengenai destinasi pariwisata Pulau Untung Jawa dengan 4 pilihan jawaban yang diberi nilaidari 1 sampai 4 , yang selanjutnya dihitung nilai rata-rata dari masing-masing indikator atau masing-masing pertanyaan dengan dengan ketentuan seperti pada Tabel 5.

Tabel 5. Nilai, Nilai Rata-rata dan Kriteria Mengenai Kualitas Destinasi Pariwisata

\begin{tabular}{|l|l|l|}
\hline Nilai & Nilai Rata-rata & Kriteria \\
\hline 1 & $1,00-1,55$ & Sangat Tidak Baik \\
\hline 2 & $1,56-2,55$ & Tidak Baik \\
\hline 3 & $2,56-3,55$ & Baik \\
\hline 4 & $3,56-4,00$ & Sangat Baik \\
\hline
\end{tabular}




\section{HASIL DAN PEMBAHASAN}

\section{Karakteristik Wisatawan Pulau Untung Jawa}

Karakteristik wisatawan Pulau Untung Jawa yaitu sebagai berikut :

1. Berdasarkan Jenis Kelamin :jumlah laki-laki 53 persen dan perempuan 47 persen. Laki-laki lebih banyak dari perempuan, menunjukkan bahwa objek wisata Pulau Untung Jawa di Kepulauan Seribu lebih diminati oleh laki-laki dibanding perempuan karena berwisata ke Pulau Untung Jawa diperlukan keberanian untuk menyeberang dengan menggunakan kapal motor yang terbuat dari kayu.

2. Berdasarkan Usia :Usia dapat mencerminkan kondisi fisik seseorang dan dapat menentukan orang untuk melakukan perjalanan wisata. Dilihat dari faktor usia wisatawan yaitu 28 persen berusia kurang dari 20 tahun, 38 persen wisatawan berusia sekitar 21 sampai 30 tahun, 14 persen wisatawan berusia sekitar 31 sampai 40 tahun, dan berusia sekitar 41 sampai 50 tahun, serta 6 persen wisatawan yang berusia lebih dari 50 tahun. Dengan demikian yang paling banyak berkunjung ke Pulau Untung Jawa berkisar antara usia kurang dari 20 tahun sampai 30 tahun yaitu sebanyak 76 persen. Hal tersebut karena pada usia tersebut memiliki tenaga yang kuat untuk melakukan perjalanan wisata dan memiliki rasa ingin tahu serta memiliki rasa penasaran yang tinggi.

3. Berdasarkan Tingkat Pendidikan :Tingkat pendidikan dapat menentukan seseorang dalam memilih destinasi wisata. Dilihat dari Pendidikan yaitu yang berpendidikan terakhir SD (Sekolah Dasar) hanya 2 persen, yang berpendidikan SMP sebanyak 16 persen, dari yang berpendidikan terakhir SMA sebanyak 62 persen yang berpendidikan terakhir D3 sebanyak 10 persen, yang berpendidikan terakhir S1 sebanyak 4 persen, danyang berpendidikan terakhir S2 sebanyak 6 persen.

4. Berdasarkan Asal Daerah: Wisatawan adalah orang yang bepergian dari daerah asal ke daerah yang dituju dengan tujuan utama untuk bersenang-senang atau menghilangkan rasa strees dan bermaksud tidak menetap di daerah tujuan. Wisatawan yang datang ke Pulau Untung Jawa berasal dari daerah Jabodetabek (Jakarta, Bogor, Depok, Tangerang, Bekasi), yang paling banyak berasal dari Tangerang yaitu sebanyak 38 persen, berasal dari Jakarta sebanyak 29 persen, yang berasal dari Bogor sebanyak 13, dan dari Bekasisebanyak 12 persen, yang paling sedikit berasal dari wilayah Depok yaitu 8 persen. Banyaknya wisatawan yang berasal dari Tangerang karena Tangerang lebih dekat ke daerah Tanjung Pasir yaitu tempat menyeberang atau naik kapal untuk menuju Pulau Untung Jawa, juga pulau Untung Jawa letaknya lebih dekat dengan wilayah Tangerang.

5. Berdasarkan Pekerjaan: Salah satu tujuan dari berwisata adalah untuk bersenangsenang atau untuk menghilangkan rasa jenuh atau rasa penat dari aktivitas pekerjaan. Setelah berwisata diharapkan merasa segar sehingga semangat kerja meningkat kembali, terdapat 32 persen wisatawan yang datang ke Pulau Untung Jawa adalah pelajar/mahasiswa, 2 persen wisatawan bekerja sebagai pegawai negeri, 32 persen wisatawan yang bekerja sebagai pegawai swasta, 12 persen wisatawan bekerja sebagai wiraswasta, dan 22 persen wisatawan yang bekerja di bidang lainnya yaitu sebagai ibu rumah tangga. Berdasarkan hasil penelitian dapat 
dilihat bahwa wisatawan yang datang ke Pulau Untung Jawa berasal dari berbagai golongan pekerjaan, namun pengunjung yang banyak datang ke Pulau Untung Jawadidominasi oleh para pelajar/mahasiswa dan pegawai swasta.

6. Berdasarkan Pendapatan : Untuk berwisatadiperlukan uang paling tidak yang digunakan untuk biaya tranfortasi, dan kebutuhan untuk makan. Sehingga orang akan menyisihkan penda-patannya jika akan berwisata. Karakteristik wisatawan yang datang ke Pulau Un-tung Jawa yaitu bahwa jumlah wisatawan yang berpendapatan Rp. 1.000.000sampai Rp 3.000.000 sebanyak 60 persen, yang pendapatannya Rp. 3.000.001 sampai Rp 5.000.000 sebanyak 22 persen, yang berpendapatan Rp 5.000.001 sampai Rp 7.000.000 sebanyak 6 persen, dan yang berpendapatan lebih dari Rp. 7.000.000 sebanyak 12 persen. Berdasarkan hasil penelitian tersebut wisatawan yang banyak berkunjung yang berpenghasilan sekitar Rp. 1.000.000 sampai Rp3.000.000.

7. Berdasarkan Jumlah Kunjungan : jumlah kunjungan yang dilakukan wisatawan dapat digunakan sebagai ukuran tingkat kepuasan dan loyalitas wisatawan. Jumlah kunjungan yang telah dilakukan oleh wisatawan ke Pulau Untung Jawa paling banyak yaitu baru pertama kali (satu kali ) $=44$ persen persen, yang melakukan kunjungan 2 sampai 3 kali $=32$ persen, yang telah melakukan kunjungan 4 sampai 5 kali $=14$ persen, yang telah melakukan kunjungan 6 sampai 7 kali sebanyak 8 persen, dan ada yang telah melakukan kunjungan lebih dari 7 kali yaitu sebanyak 2 persen.Dengan demikian ada 56 persen wisatawan yang telah berkunjung ke Pulau Untung Jawa lebih dari 2 kali

8. Berdasarkan Rencana Datang Kembali : Rencana wisatawan untuk datang kembali ke Pulau Untung Jawa dapat digunakan sebagai ukuran tingkat kepuasan dan loyalitas wisatawan berkunjung ke Pulau Untung Jawa. Gambaran rencana wisatawan untuk datang kembali ke Pulau Untung Jawa bahwa sebagaian besar wisatawan berencana akan datang lagi ke Pulau Untung Jawa yaitu sebanyak 94 persen, dan hanya 6 persen yang berencana untuk tidak datang lagi. Hal ini menunjukkan bahwa sebagian besar wisatawan merasa puas berkunjung ke Pulau Untung Jawa, dan menunjukkan loyal dengan Pulau Untung Jawa.

9. Berdasarkan Menginap atau Tidak Menginap : Untukmenuju Pulau Untung Jawa dapat dilakukan dengan menggunakan kapal motor dari Tanjung Pasir dengan lama perjalanan sekitar 20 sampai 30 menit. wisatawan yang datang ke Pulau Untung Jawa sebagaian besar tidak menginap yaitu sebanyak 78 persen, sedangkan yang menginap sebanyak 22 persen. Sedikitnya wisatawan yang menginap dikarenakan kalau menginap diperlukan biaya yang cukup besar karena harus menyewa home stay, juga diperlukan perbekalan makanan yang lebih banyak atau harus mengeluarkan uang untuk makan. Tapi kalau tidak menginap perbekalan untuk makan cukup bawa dari rumah.

\section{Destinasi Pariwisata Pulau Untung Jawa Kepulauan Seribu Jakarta}

Dalam mengukur destinasi pariwisata pada penelitian ini digunakan 3 dimensi yaitu : 1. Daya Tarik wisata,2.Fasilitas wisata, dan 3. Aksesibilitas. Dari 3 dimensi tersebut dibuat 14 pertanyaan (indikator) yang digunakan dengan skor jawaban terendah 
sama dengan 1 dan skor tertinggi adalah 4 dalam mengukur variabel daya tarik tujuan wisata Pulau Untung Jawa Kepulauan Seribu.

\section{Daya Tarik Wisata Pulau Untung Jawa}

Wisata Pulau Untung Jawa merupakan wisata pantai sehingga yang ditanyakan kepada wisatawan yaitu mengenai : 1 . Keindahan alam pantai, 2. Keindahan terumbu karang/wisata bawah air, 3. Kebersihan pantai.

Wisatawan datang ke Pulau Untung Jawa selain menikmati keindahan alam pantai juga menikmati keindahan terumbu karang/wisata bawah air. Untuk menikmati keindahan terumbu karang/wisata bawah air wisatawan harus menyewa perahu motor kecil yang bisa muat sekitar 10 orang biasanya menuju dekat pulau Rambut. Menyewa perahu tidak harus diboking satu perahu melainkan sewa bias diberlakukan per orang. Biaya sewa perahu dan perlengkapan snorkling Rp 50.000 per orang, namun sebenarnya masih bisa ditawar, apalagi kalau jumlah wisatawan tidak terlalu banyak, jika ditawar bisa Rp 30.000 atau Rp 40.000 per orang dengan jarak tempuh sekitar 20 menit dan lama snorkling sekitar 30 sampai 45 menit.

Wisatawan datang ke destinasi wisata selain penasaran dan ingin menikmati keindahan destinasi wisata tersebut, juga menginginkan tempat tersebut terjaga kebersihannya karena kalau kotor atau banyak sampah bisa mengganggu keindahan pemandangan yang akan dinikmati.

\section{Fasilitas Pariwisata}

Fasilitas Wisata merupakan unsur penting pembentuk produk pariwisata yang berperan menunjang kemudahan dan kenyamanan wisatwan, seperti; ketersediaan sarana akomodasi, prasarana wisata dan sarana wisata pendukung lainnya dalam radius tertentu. Pada penelitian ini fasilitas pariwisata yang dikaji terdiri dari: 1. Ketersediaan Penginapan, 2. Keterjangkauan Harga Penginapan,

3. Ketersediaan Penjual Makanan dan Minuman, 4. Keterjangkauan Harga Makanan dan Minuman, 5. Ketersediaan Fasilitas Permainan Air, 6. Keterjangkauan Harga Fasilitas Permainan Air, dan 7. Ketersediaan Air Bersih di Pulau Untung Jawa.

Keberadaan penginapan berupa homestay menjadi daya tarik tujuan wisata pada wisatawan dalam berkunjung. Keberadaan homestay membuat wisatawan berada pada lingkungan rumah yang ramah dan merasa dekat dengan penduduk lokal di Pulau Untung Jawa. Berwisata ke Pulau Untung Jawa bisa dilakukan tanpa harus menginap karena menyeberang dari Tanjung Pasir sekitar 30 menit, namun kalau ingin merasa puas dan dapat mengelilingi dan ingin menikmati keindahan alam pantai secara lebih leluasa sebaiknya menginap di Pulau Untung Jawa. Penginapan berupa rumah penduduk yang disewakan kepada wisatawan yang dilengkapi pendingin udara ( $\mathrm{AC} / \mathrm{kipas}$ angina) atau lebih dikenal dengan intilah homestay banyak tersedia. Harga yang per kamar dengan fasilitas AC dan kamar mandi di dalam bisa ditempati 2 sampai 3 orang Rp 300.000, namun kalau tidak melalui calo dan sedang sepi bisa ditawar Rp

200.000. Rumah dengan 2 kamar ada ruang tamu dilengkapi AC harga sekitar Rp 700.000 sampai Rp 800.000. Sedangkan Rumah dengan 3 kamar tidur ada ruang tamu dilengkapi AC harga sekitar Rp 1.000.000 sampai Rp 1.200.000.

Setelah sampai di daerah tujuan wisata biasanya wisatawan memerlukan makanan dan minuman sebagai kebutuhan utama, bagi wisatawan yang tidak membawa perbekalan makanan dan minuman mereka akan membelinya di daerah tujuan wisata. Harga makanan Seafood + nasi + minum per porsi berkisar antara Rp 50.000 sampai Rp 
80.000, harga paket super hemat (ayam + nasi + minum) per porsi Rp 50.000,-, sedangkan harga nasi goreng telor + teh manis per porsi Rp 25.000,--

Wisatawan pergi berwisata tidak hanya menikmati keindahan alamnya tetapi juga membutuhkan fasilitas pendukung lainnya diantaranya yaitu fasilitas permainan agar tidak merasa bosan dan bisa menikmati sensasi lainnya. Karena wisata alam di Pulau Untung Jawa adalah wisata pantai, maka fasilitas permainan yang perlu ada yaitu fasilitas permainan air seperti donat, banana boat, dan snorkling. Harga paket permainan donut dan banana boat Rp 35.000 per orang untuk lama waktu sekitar 15 menit, namun harga tersebut masih bisa ditawar menjadi Rp 20.000 per orang. Harga paket snorkling untuk sewa perahu dan perlengkapan lainnya Rp 50.000 untuk waktu sekitar 1 jam sampai 1,5 jam, harga paket snorking bisa ditawar menjadi Rp 35.000 per orang.

\section{Aksesibilitas}

Aksesibilitas merupakan salah satu unsur utama berkembangnya pengunjung suatu destinasi wisata. Aksesibilitas suatu destinasi wisata diantaranya dapat diukur dari ketersedian dan keadaan transportasi menuju objek wisata dan di tempat wisata. Akses menuju Pulau Untung Jawa sangat mudah dijangkau melalui transportasi laut yang sudah memadai, baik yang miliki masyarakat maupunpemerintah. Terdapat beberapa akses untuk menuju ke Pulau Untung Jawa, yaitu:

1. Dari Pelabuhan Tanjung Pasir

Tanjung Pasir merupakan desa daerah pesisir yang terletak di Kecamatan TelukNaga, Kabupaten Tangerang Banten. Tanjung Pasir difungsikan sebagai pelabuhan dantempat penyeberangan menuju ke Pulau Untung Jawa. Akses menuju Pulau Untung Jawa dari Pelabuhan Tanjung Pasir hanyamembutuhkan waktu tempuh sekitar 20 sampai 30 menit dengan menggunakan kapal kayu. Kapal-kapal kayu tersebut merupakan milik masyarakat lokal yang dikelolasebagai jasa transportasi untuk memudahkan masyarakat dan wisatawan yangmelakukan perjalanan menuju Pulau Untung Jawa.

2. Dari Kali Adem

Selain transportasi milik masyarakat lokal, pemerintah juga menyediakan transportasi laut yang memudahkan masyarakat dan wisatawan yangakan melakukan penyeberangan ke pulau-pulau lain yang ada di Kepulauan Seribu sesuai rute yang ingin dituju. Untuk menuju Pulau Untung Jawa,wisatawan dapat menggunakan kapal Lumba-lumba atau yang sering disebut masyarakat sebagai kapal Trans Jakarta. Kapal Trans Jakarta yang dikelola oleh Dinas Perhubungan Provinsi DKI Jakarta memiliki dua armada kapal yaitu Lumba lumba I dan Lumba-lumba II dengan tarif Rp 45.000,00/orang. Berangkat dari Kali Adem jam 8.00pagi, berhenti di Dermaga Pulau Untung Jawa hanya sekitar 10 menit yaitu untuk menaikan atau menurunkan penumpang.

Selain transportasi yang ada mudah atau tersedia, nyaman, dana aman, juga transportasi tersebut harganya harus terjangkau. Pada penelitian ini indikator aksesibilitas yaitu : 1. Kemudahan transportasi menuju Pulau Untung Jawa, 2. Kenyamanan transportasi menuju Pulau Untung Jawa, dan 3. Keamanan transportasi menuju Pulau Untung Jawa.

Berdasarkan hasil penelitian mengenai indikator destinasi pariwisata Pulau Untung Jawa yang telah dijelaskan di atas, maka dapat dibuat rekapitulasinya yang disajikan pada Tabel 6 . 
Tabel 6. Rekapitulasi Kualitas Destinasi Wisata Pulau Untung Jawa

\begin{tabular}{|l|l|l|l|}
\hline No & Destinasi Wisata & $\begin{array}{l}\text { Nilai } \\
\text { Rata-rata }\end{array}$ & Kriteria \\
\hline \multicolumn{2}{|l|}{ Daya Tarik Wisata } & $\mathbf{3 , 2 1}$ & Baik \\
\hline 1 & Keindahan Alam Pantai & 3,80 & $\begin{array}{l}\text { Sangat Indah/ } \\
\text { Sangat Baik }\end{array}$ \\
\hline 2 & Keindahan terumbu karang & 2,99 & Indah/Baik \\
\hline 3 & Kebersihan Pantai & 2,84 & Bersih/Baik \\
\hline Fasilitas Pariwisata & $\mathbf{2 , 9 5}$ & Tersedia/Baik \\
\hline 4 & Ketersediaan Penginapan & 3,12 & Tersedia/Baik \\
\hline 5 & Keterjangkauan Harga Penginapan & 2,96 & Terjangkau/Baik \\
\hline 6 & Ketersediaan Penjual Makanan dan Minuman & 3,03 & Tersedia/Baik \\
\hline 7 & Keterjangkauan Harga Makanan dan Minuman & 2,58 & Terjangkau/Baik \\
\hline 8 & Ketersediaan Fasilitas Permainan Air & 3,33 & Tersedia/Baik \\
\hline 9 & Keterjangkauan Harga Fasilitas Permaian Air & 2,70 & Terjangkau/Baik \\
\hline 10 & Ketersediaan Air Bersih & 2,92 & Tersedia/Baik \\
\hline Aksesibilitas & $\mathbf{2 , 8 6}$ & Baik \\
\hline 11 & Kemudahan Transportasi & 2,89 & Mudah/Baik \\
\hline 12 & Kenyamanan Transportasi & 2,76 & Nyaman/Baik \\
\hline 13 & Keamanan Transportasi & 2,82 & Aman/Baik \\
\hline 14 & Keterjangkauan Biaya Transportasi & 2,96 & Terjangkau/Baik \\
\hline Rata-rata & $\mathbf{3 , 0 0}$ & Baik \\
\hline
\end{tabular}

Sumber : Data Primer diolah, 2018

Dari Tabel 6 dapat dilihat bahwa dimensi kualitas destinasi pariwisata Pulau Untung Jawa dengan nilai rata-rata paling tinggi yaitu mengenai daya Tarik wisata dengan nilai rata-rata $=3,21$ dapat dikatakan termasuk kategori menarik/baik. Nilai rata- rata terendah untuk dimensi daya tarik yaitu mengenai kebersihan pantai dengan nilai ratarata $=2,84$ meskipin masih termasuk kategori bersih/baik.

Rendahnya nilai rata-rata mengenai kebersihan pantai dikarenakan banyaknya sampah plastik dan sampah lainnya yang ada di sekitar pantai dan juga di sekitar hutan mangrove yang membuat keindahan pantai dan keindahan hutan mangrove berkurang. Banyaknya sampah tersebut sebagian besar adalah sampah yang berasal dari daratan Jakarta dan Tangerang yang terbawa gelombang air laut.

Nilai rata-rata kedua tertinggi adalah mengenai dimensi fasilitas pariwisata dengan nilai rata-rata $=2,95$ termasuk kategori baik. Nilai rata-rata terendah untuk dimensi fasilitas pariwisata yaitu mengenai keterjangkauan harga makanan dan minuman dengan nilai rata-rata $=2,58$ meskipun termasuk kategori terjangkau/baik. Rendahnya penilaian mengenai keterjangkauan harga makanan dan minuman dikarenakan sebagian besar responden datang ke Pulau Untung Jawa berpendapatan 
rendah yaitu kurang atau sama dengan Rp 3.000.000,- per bulan ( 60 persen), sedangkan yang berpendapatan lebih dari Rp 7.000.000,- per bulan hanya 12 persen.

Nilai rata-rata terendah untuk ketiga dimensi yang diteliti yaitu mengenai dimensi Aksesibilitas dengan nilai rata-rata $=2,86$ meskipun masih termasuk kategori baik. Penilaian rata-rata yang paling rendah untuk dimensi aksesibilitas yaitu mengenai kenyamanan transfortasi menuju Pulau Untung Jawa dengan nilai rata-rata $=2,76$ meskipun masih termasuk kategori nyaman/baik. Rendahnya nilai rata-rata kenyamanan transportasi menuju Pulau Untung Jawa dari Daerah Tanjung Pasir dengan menggunakan kapal motor yang terbuat dari kayu yang pemilik kapal tersebut adalah masyarakat sekitarnya (Tanjung Pasir dan Pulau Untung Jawa) karena kapal berangkat menunggu penumpang penuh, sehingga penumpang duduk berdesak-desakan.

Dari Tabel 6 juga dapat dilihat bahwa nilai rata-rata dari semua indikator (14 indikator) destinasi pariwisata $=3$ (kategori baik). Indikator destinasi yang memperoleh nilai lebih rendah dari rata-rata yaitu : 1) Keindahan terumbu karang $=2,99 ; 2$ ) Kebersihan pantai $=2,84 ; 3$ ) Keterjangkauan harga penginapan $=2,96 ; 4$ ) Keterjangkauan harga makanan dan minuman $=2,58 ; 5)$ Keterjangkauan harga fasilitas permainan air $=$ 2,70 ; 6) Ketersediaan air bersih $=2,92$; 7) Kemudahan transportasi $=2,89$; 8) Kenyamanan transportasi $=2,76$; 9) Keamanan transportasi $=2,82$; 10) Keterjangkauan biaya transportasi $=2,96$. Indikator destinasi yang memperoleh nilai lebih besar dari ratarata yaitu : 1) Keindahana alam pantai $=3,80 ; 2$ ) Ketersediaan penginapan $=3,12 ; 3$ ) Ketersediaan penjual makanan dan miniman $=3,03$; 4) Ketersediaan fasilitas permainan air $=3,33$. Dengan demikian dari 14 indikator tersebut 10 indikator nilai rata-ratanya lebih rendah dari rata-rata keseluruhan dan hanya 4 indikator yang nilai rata-ratanya lebih besar dari rata-rata keseluruhan.

\section{KESIMPULAN DAN SARAN}

\section{Kesimpulan}

Kesimpulan dari hasil penelitian ini yaitu:

1. Karakteristik wisatawan yang datang ke Pulau Untung Jawa Kepulauan Seribu Jakarta yaitu : 1) Paling banyak laki-laki (53 persen), 2) Paling banyak (76 persen) berusia 17 tahun sampai 30 tahun, 3) Paling banyak (62 persen) berpendidikan SLTA, 4) Paling banyak (38 persen) berasal dari wilayah Tangerang, 5) Paling banyak (64 persen) pelajar/mahasiswa dan pegawai swasta, 6) Paling banyak (60 persen) berpendapatan kurang atau sama dengan Rp 3.000 .000 per bulan, 7) Paling banyak (76 persen) berkunjung 1 kali sampai 3 kali, 8) Paling banyak ( 94 persen ) berencana akan datang lagi, 9) Paling banyak (78 persen) tidak menginap.

2. Penilaian wisatawan mengenai destinasi pariwisata Pulau Untung Jawa di Kepulauan Seribu Jakarta dengan skala penilaian 1 sampai 4, diperoleh rata-rata $=$ 3.00 (kategori baik). Indikator destinasi yang memperoleh nilai lebih besar dari ratarata yaitu : 1) Keindahana alam pantai ; 2) Ketersediaan penginapan;

3) Ketersediaan penjual makanan dan miniman ;4) Ketersediaan fasilitas permainan air. Indikator destinasi yang memperoleh nilai lebih rendah dari rata-rata yaitu :Keindahan terumbu karang; 2) Kebersihan pantai; 3) Keterjangkauan harga penginapan; 4) Keterjangkauan harga makanan dan minuman; 5) Keterjang-kauan harga fasilitas permainan air; 6) Ketersediaan air bersih; 7) Kemudahan transportasi; 8) Kenyamanan transportasi; 9) Keamanan transportasi ; 10) Keterjangkauan biaya transportasi. 


\section{Saran}

Berdasarkan hasil penelitian maka dapat dibuat saran sebagai berikut :

1. Pihak pemerintah, masyarakat, dan pengelola kawasan wisata Pulau Untung Jawa hendaknya secara bersama-sama berusaha untuk mempertahankan dan meningkatkan kualitas destinasi wisata yang ada di Pulau Untung Jawa.

2. Kebersihan pantai dan lingkungan sekitar Pulau Untung Jawa harus benar-benar dijaga agar wisatawan merasa nyaman, karena pemandangan yang indah akan terganggu jika lingkungannya kotor dan banyak sampah. Masyarakat sekitar perlu diberi pengarahan agar benar-benar menjaga kebersihan pantai dan lingkungan sekitar rumahnya. Pasukan Orange yang bertugas membersihkan lingkungan perlu diberi arahan agar Kawasan pantai dan lingkungan sekitarnya senantiasa terjaga kebersihannya.

3. Mengingat sebagian besar (60 persen) wisatawan berpendapatan kurang atau sama dengan Rp 3.000.000, maka harga makanan dan minuman dirasakan mahal oleh wisatawan sehingga kebanyakan dari wisatawan membawa bekal makanan dan minuman. Sebaiknya disediakan juga makanan yang harganya lebih murah, selain itu juga sebaiknya jangan terlalu besar mengambil keuntungan agar jumlah barang yang terjual bisa lebih banyak.

4. Kemudahan, kenyamanan, dan keamanan transportasi harus ditingkatkan. Sebaiknya dibangun dermaga di Tanjung Pasir agar mudah untuk naik ke perahu dan turun dari perahu seperti yang ada di Pulau Untung Jawa. Untuk menjaga kenyamanan wisatawan sebaiknya perahu tidak diisi penumpang dengan kapasitas maksimum sehingga duduk berdesak-desakan. Untuk menjaga keamanan selama dalam perjalanan di laut sebaiknya tersedia Jaket pengaman dalam jumlah yang sesuai dengan jumlah penumpang dan dibagikan ke penumpang untuk menjaga hal-hal yang tidak diharapkan.

\section{DAFTAR PUSTAKA}

Basiya, R. \& Rozak, H.A. (2012). Kualitas Dayatarik Wisata, Kepuasan Dan Niat Kunjungan Kembali Wisatawan Mancanegara Di Jawa Tengah. Dinamika Kepariwisataan, 11(2).

Ismayanti. (2010). Pengantar Pariwisata. Jakarta: PT Gramedia Widisarana. Jakarta.

Kirom, N.R., Sudarmiatin, S. \& Putra, I.W.J.A. (2016). Faktor-faktor Penentu Daya Tarik Wisata Budaya dan Pengaruhnya terhadap Kepuasan Wisatawan. Jurnal Pendidikan: Teori, Penelitian, dan Pengembangan, 1(3), pp.536-546.

Mayers, G.E \& Mayers, M.T. (2009). The Dynamics OF Human Communication. Sixth Edition. Mc Graw Hill, Inc: New York.

Mulyadi. (2010). Daya Tarik Wisata. Edisi Keenam. Buku 1. Salemba Empat. Jakarta.

Pendit N, S. (2010). Pengantar Ilmu Pariwisata. Pradnya Paramita. Jakarta.

Pitana, I.G. \& Putu, G., Gayatri. (2015). Sosiologi Pariwisata. Yogyakarta: Andi Offset. 
Vol 1, No. 2, 2018

Razak, A. \& Suprihardjo, R. (2013). Pengembangan Kawasan Pariwisata Terpadu di Kepulauan Seribu. Jurnal Teknik ITS, 2(1), pp.C14-C19.

Sunaryo, B. (2013). Kebijakan pembangunan destinasi pariwisata: konsep dan aplikasinya di Indonesia (No. 1). Penerbit Gava Media Kebijakan Pembangunan Destinasi Pariwisata: Konsep dan Aplikasinya di Indonesia.

Yoeti, O.A. (2009). Pengantar Ilmu Pariwisata. Angkasa Offset. Bandung. 